\title{
The Impact of Visual, Auditory, and Kinesthetic Learning Styles on Economics Education Teaching
}

\author{
Rita Syofyan ${ }^{1}$, Menik Kurnia Siwi ${ }^{2}$ \\ ${ }^{1}$ Dept. of Economics, Faculty of Economics, Universitas Negeri Padang, Padang, Indonesia \\ $\square$ (e-mail) ritasyofyanunp@gmail.com \\ ${ }^{2}$ Dept. of Economics, Faculty of Economics, Universitas Negeri Padang, Padang, Indonesia \\ $\square$ (e-mail) menikkurnia@gmail.com
}

\begin{abstract}
The purpose of this research is to analysis the impacts of visual, auditory, kinesthetic learning styles on economics education teaching. One of the most important uses learning styles is that it makes it easy for teachers to incorporate them into their teaching. There are various styles of learning. Three of the most popular are visual, auditory, and kinesthetic, in way students take the information. While students use all of their senses to take the information, they seem to have preferences in how they learn best. In order to help students to learn, teachers need to teach as many of these preferences as possible. Teachers can incorporate these learning styles in their curriculum activities so that students are able to succeed in their classes. The purpose of this study is to increase faculty awareness and understanding of the effect of learning styles on the teaching process. This study aims to conduct an analysis of learning styles for Economics Education students. A review of the literature will determine how learning styles affect the teaching process. A total of 100 students completed questionnaires to determine their learning styles. The findings show that most Economics Education students prefer visual learning style.
\end{abstract}

Keywords: leaning styles, auditory, visual, kinesthetic, and economics teaching

\section{Introduction}

The digital era requires the use of information technology in all aspects of life, especially education, the discourse of using technology will replace the function and role of teachers who will be replaced with online learning media. On the other hand, the education process is not just the delivery of information from learning resources to students, but also the changes in behavior. Each student has a different learning style cannot only be done through the delivery using digital technology. For this reason, it is necessary to have an initial assessment related to differences in learning styles that need to be adjusted to the appropriate learning methods.

The generally definition of learning styles is a characteristic cognitive, effective, and psychosocial behaviors that serve as relatively stable indicators of how learners perceive, interact with, and respond to the learning environment (MacKeracher, 2004). Learning styles may be defined in multiple ways, depending upon one's perspective. Here are a few definitions of learning styles. Brown (2000) defines learning styles as the manner in which individuals perceive and process information in learning situations. He argues that learning style preference is one aspect of learning style, and refers to the choice of one learning situation or condition over another.

The style of learning is a way to receive, process, remember and apply the information easily. Each student has a way of learning is different. Student learning styles can be recognized among the learning styles of visual, auditory and kinesthetic. Students with a visual learning style learn through what they see, auditory students learn through what they hear and kinesthetic students learn through movement and touch. Individual student learning styles tend to have different useful for learning, processing and communication, according to Bandler and Grinder (Brown, 2000). CelceMurcia (2001) defines learning styles as the general approaches-for example, global or analytic, 
auditory or visual - that students use in acquiring a new language or in learning any other subject. The manner in which a learner perceives, interacts with, and responds to the learning environment.

There are three main learning styles, namely, visual, auditory, and kinesthetic. The definitions of these learning styles are as follows: Visual learners think in pictures and learn best in visual images. They depend on the instructor's or facilitator's non-verbal cues such as body language to help with understanding. Sometimes, visual learners like sitting in the front of the classroom. They also take descriptive notes over the material being presented. Auditory, these individuals discover information through listening and interpreting information by the means of pitch, emphasis and speed. These individuals gain knowledge from reading out loud in the classroom and may not have a full understanding of information that is written. Kinesthetic learner, individuals that are kinesthetic learn best with and active "hands-on" approach. These learners like interaction with the physical world. Most of the time kinesthetic learners have a difficult time staying on target and can become unfocused effortlessly (Pride, 2009).

According DePorter (1999), each the learning style can be explained that visual learning style access visual images created nor remembered. color, spatial relations, mental portraits and images stand out in this learning style. Students were very visual possibly characterized as follows. First, the students regularly pay attention to everything, to keep up appearances. Second, students learn by viewing images rather than read out. Finally, students require thorough overview and objectives to capture details and remember what they saw.

Whereas auditory learning style accesses all kinds of sounds and words that created nor remembered. Music, tone, rhythm, rhyme, internal dialogue and a prominent voice in this learning style. Students were very auditory can be characterized as follows. First, the students' attention is split. Second, the students talk to the rhythmic pattern. Third, students learn by listening and moving the lips/voice while reading. Finally, students tend to have a dialogue internally and externally (DePorter, 1999).

In contrast, kinesthetic learning style accesses all types of motion and emotion created nor remembered. Movement, coordination, rhythm, emotional response and physical comfort prominently in this learning style. Students were very kinesthetic may be characterized as follows. First, students tend to like touching people, stand close together and a lot of moves. Second, students learn by doing, pointing/writing while reading, and responding physically. Finally, students love go and see (DePorter, 1999).

\section{Methods}

Method section explains clearly how you conducted your study in order to enable readers to evaluate the work performed (Biggs, 2001) and permit others to replicate your study (Blouin, 2008). The section must describe exactly what the researcher did, what and how experiments were run, what, how much, how often, where, when, and why equipment and materials were used. The main consideration is to ensure that enough detail is provided to verify your findings and to enable the replication of the study. The study should maintain a balance between brevity and completeness.

This study conducted a review of the literature to determine how learning styles affect the teaching process. Moreover, a survey questionnaire was carried out in this study. A total of 100 students completed questionnaires to determine their learning styles.

\section{Results and Discussion}

\section{The visual, auditory, and kinesthetic learning styles in Deartment of Economics Education}

Identifying learning styles of the students of economics education used to learn how to learn each student. By knowing the student's learning style, students can learn according to their learning style 
so student results can be improved. Tabulation of data owned student learning styles of economics education student can be seen in the table below.

Table 1 Number of students based on learning styles in Department of Economics Education

\begin{tabular}{ccc}
\hline Learning Style & Fi & Percentage \\
\hline Visual & 48 & $48 \%$ \\
\hline Auditory & 34 & $34 \%$ \\
\hline Kinesthetic & 18 & $18 \%$ \\
\hline Total & 100 & $100 \%$ \\
\hline
\end{tabular}

Based on the above table, it can be seen that there are 48 students in Economics Education who have visual learning style, 34 students have auditory learning style, and 18 students have kinesthetic learning style. Figure 1 presents the percentage of students' learning styles in Economics Education. Overall, students of Economics Education Department were dominated by $48 \%$ of those with the tendency for visual style learning.

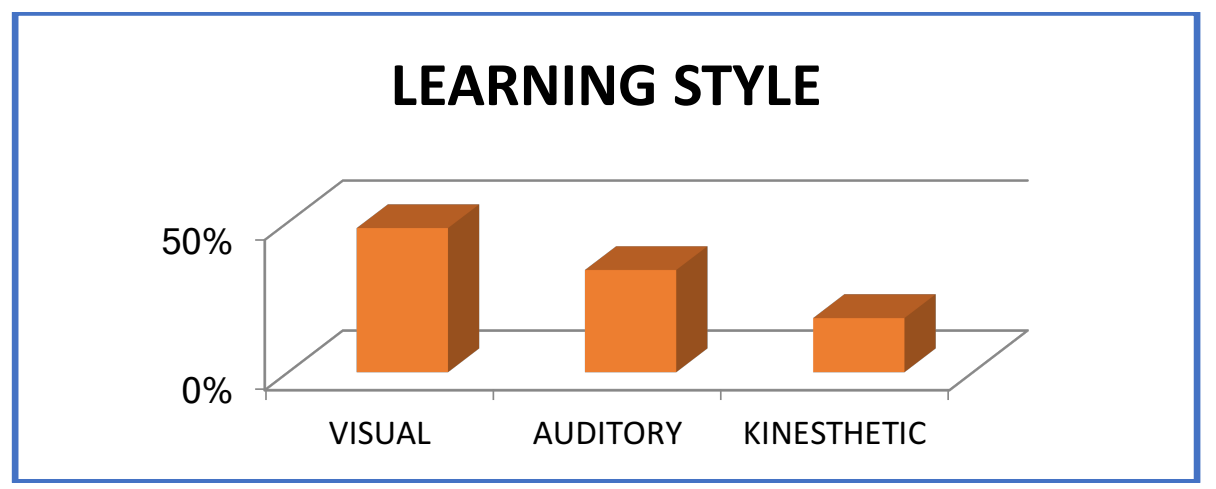

Figure 1 Percentage of Student Learning Styles economics education

\section{The applications of learning styles in the classroom}

Class sizes increase, so do the types and numbers of student learning styles. Also, as previously mentioned, internationalization and changes in the media culture may affect the spectrum of classroom learning styles as well (Garsha, 1990). Given the variability in learning styles that may exist in a classroom, some authors suggested that students should adapt their learning styles to coincide with a given instruction style (De Vita, 2001). This allows instructors to dictate the methods used to instruct in the classroom. This approach also allows instructors to "teach from their strengths," with little consideration to other external factors such as learning style of students. While convenient, this unilateral approach has been criticized for placing all of the responsibility for aligning teaching and learning on the student.

When the majority of information is presented in formats that are misaligned with learning styles, students may spend more time manipulating material than they do in comprehending and applying the information. Additionally, a unilaterally designed classroom may reinforce a "do nothing" approach among faculty members (De Vita, 2001). Alternatively, a teaching style-learning style mismatch might challenge students to adjust, grow intellectually, and learn in more integrated ways. However, it may be difficult to predict which students have the baseline capacity to adjust, particularly when significant gaps in knowledge of a given subject already exist or when the learner is a novice to the topic being instructed (De Vita, 2001). This might be especially challenging within professional curricula where course load expectations are significant.

Best practice most likely involves a teaching paradigm which addresses and accommodates multiple dimensions of learning styles that build self-efficacy (Felder, 1993). Instructing in a way that encompasses multiple learning styles gives the teacher an opportunity to reach a greater extent of a 
given class, while also challenging students to expand their range of learning styles and aptitudes at a slower pace. This may avoid lost learning opportunities and circumvent unnecessary frustration from both the teacher and student. For many instructors, multi-style teaching is their inherent approach to learning, while other instructors more commonly employ unilateral styles. Learning might be better facilitated if instructors were cognizant of both their teaching styles and the learning styles of their students. An understanding and appreciation of a given individual's teaching style requires selfreflection and introspection and should be a component of a well-maintained teaching portfolio. Major changes or modifications to teaching styles might not be necessary in order to effectively create a classroom atmosphere that addresses multiple learning styles or targets individual ones. However, faculty members should be cautious to not over ambitiously, arbitrarily, or frivolously design courses and activities with an array of teaching modalities that are not carefully connected, orchestrated, and delivered.

\section{Learning for Visual Students}

Here are some characteristics of learning that should be used on students with learning styles tendency visual, auditory, or kinesthetic. Students who are very visual has several characteristics as follows (DePorter, 2014).

1) Regularly, pay attention to everything, to keep up appearances;

2) In view of the image, rather read than read out; and

3) Requires a thorough overview and objectives.

Thus, some of the characteristics of learning appropriate for students who are very visual is as follows:

a. Lecturer stood quietly when presenting segment information, and move slowly among the segments;

b. Give encouragement to students to describe the information, by creating a diagram, symbol and color images in Visual student records;

c. The Tables and Graphs will deepen students' understanding of Visual especially in mathematics, engineering, or science;

d. The making map mind / concept maps will be helpful in giving students Visual "overall picture" of a concept;

e. Use the language of visual symbols in the presentation faculty representing key concepts;

f. Familiarize the student to take back the material / information by using different colors / images are interesting;

g. Note the lighting or lighting a room while teaching / learning takes place.

h. Use of instructional media such as books, magazines, posters, computer / LCD, Collage, Flow charts, highlighting, keyword displayed around the classroom, writing with attractive colors.

\section{Learning for Auditory Students}

Students were very auditory has several characteristics as follows [De Porter, 2014]:

a. Attention is fragmented

b. Speak with a rhythmic pattern;

c. Learn by listening, moving her lips / voice while reading;

d. Internal and external dialogue.

In accordance with the characteristics of auditory student, here are some of the characteristics of learning appropriate:

a. Provide information repeatedly, can take advantage of these questions;

b. Use the technique of repetition, ask students to name the concept and guidelines;

c. Lecturers using vocal variety in the presentation;

d. Sing A key concept or ask students to make a song related to the concept;

e. Give encouragement to students for making / thinking "mnemonics" to make it easier to memorize/recall key concepts; 
f. Use the technique of question and answer;

g. Using question and answer, role play, group work, techniques mnemonics;

h. Engage in learning music.

\section{Learning for Kinesthetic Students}

Movement, coordination, rhythm, emotional response, and physical comfort is very prominent in students who are very kinesthetic. In accordance with those disclosed in DePorter et al. that some of the characteristics of someone who kinesthetic, among others:

1. Often touch people, standing close together and moving when interacting with others;

2. Learn by doing;

3. Appoint writing while reading;

4. Given the go and see

Therefore, here are some of the characteristics of student learning according to a very kinesthetic, among others:

a. Kinesthetic students preferred form of project tasks applied;

b. Use of instructional media / tools when teaching to generate curiosity and emphasize key concepts;

c. Kinesthetic allow students to walk in the classroom;

d. Demonstrate concepts while providing the opportunity for students to learn step by step;

e. Create a simulation of the concept that the student experience;

f. Create mind maps involving physical activity can also be useful for students kinesthetic.

Based on the above results, there are also some students who have a tendency combination of several styles of learning, it should be a lecturer is expected to create learning that combines some characteristics of these learning styles. Various researchers have attempted to provide ways in which learning styles can take effect in the classroom. Dunn and Dunn write that "learners are affected by their: (1) immediate environment (sound, light, temperature, and design); (2) own emotionality (motivation, persistence, responsibility, and need for structure or flexibility); (3) sociological needs (self, pair, peers, team, adult, or varied); and (4) physical needs (perceptual strengths, intake, time, and mobility)" (Dunn, \& Dunn, 1978). They claim that not only can students identify their preferred learning styles, but that students also score higher on tests, have better attitudes, and are more efficient if they are taught in ways to which they can more easily relate. Therefore, it is to the educator's advantage to teach and test students in their preferred styles (Dunn, \& Dunn, 1978).

Although learning styles will inevitably differ among students in the classroom, Dunn and Dunn (1978) say that teachers should try to make changes in their classroom that will be beneficial to every learning style. Some of these changes include room redesign, the development of small-group techniques, and the development of Contract Activity Packages. Redesigning the classroom involves locating dividers that can be used to arrange the room creatively, clearing the floor area, and incorporating student thoughts and ideas into the design of the classroom (Dunn, \& Dunn, 1978).

Small-group techniques often include a "circle of knowledge" in which students sit in a circle and discuss a subject collaboratively as well as other techniques such as team learning and brainstorming. Contract Activity Packages are educational plans that facilitate learning by using the following elements: 1) clear statement of what the students' needs to learn; 2) multisensory resources (auditory, visual, tactile, kinesthetic) that teach the required information; 3) activities through which the newlymastered information can be used creatively; 4 ) the sharing of creative projects within small groups of classmates; 5) at least 3 small-group techniques; 6 ) a pre-test, a self-test, and a post-test (Dunn, \& Dunn, 1978). 


\section{The significance of learning style}

Students come to colleges with varied ethnic and cultural backgrounds, from a multitude of training programs and institutions, and with differing learning styles (Bollinger, 2003). Coupled with this increase in diversification has been a growth in distance education programs and expansions in the types of instructional media used to deliver information (Blouin, 2008). These changes and advances in technology have led many educators to reconsider traditional, uniform instruction methods and stress the importance of considering student learning styles in the design and delivery of course content (Lubawy, 2003). Mismatches between an instructor's style of teaching and a student's method of learning have been cited as potential learning obstacles within the classroom and as a reason for using a variety of teaching modalities to deliver instruction (Cook, 2005. The concept of using a menu of teaching modalities is based on the premise that at least some content will be presented in a manner suited to every type of learner within a given classroom or course. Some research has focused on profiling learning types so that instructors have a better understanding of the cohort of students they are educating (Cook, 2005). This information can be used to guide the selection of instruction modalities employed in the classroom.

One of the most significant issues in learning to learn is an individual's taking the responsibility for his/her own learning. The individuals should know what their own learning styles are and what characteristics this style has and they should thereby behave according to this style. In this way, the individual can acquire the constantly changing and increasing amount of information without need for the assistance of others. When the learner takes the responsibility of his/her own learning, s/he attributes meaning to the process of learning. $\mathrm{S} /$ he develops an understanding of his/her own form of learning style and becomes much more satisfied with the environment $\mathrm{s} / \mathrm{he}$ interacts with. Every opportunity for learning is a chance for him/her. It is in the learner's hand to use different ways and develop the learning styles to some extent (Coffield, 2004).

Learning style is important for many reasons; however, there are three vital ones. First of all, people's learning styles will vary because everyone is different from one another naturally. Secondly, it offers the opportunity to teach by using a wide range of methods in an effective way. Sticking to just one model unthinkingly will create a monotonous learning environment, so not everyone will enjoy the lesson. In other words, learning and teaching will be just words and not rooted in reality. Thirdly, we can manage many things in education and communication if we really recognize the groups we are called to. Of course, teachers may not know every detail; however, being aware of their students' learning styles, psychological qualities and motivational differences will help us regulate our lessons appropriately and according to the conditions (Coffield, 2004).

\section{The advantages of identifying learning style}

Learning style has an important place in the lives of individuals. When the individual knows his/her learning style, s/he will integrate it in the process of learning so s/he will learn more easily and fast and will be successful. Another advantage of the identification of the own learning style by the student is that it will help the student to become an effective problem solver. The more successful the individual is at solving the problems $\mathrm{s} / \mathrm{he}$ faces, the more control $\mathrm{s} /$ he will take over his/her own life (Biggs, 2001). It is important that individuals receive education in areas suitable for their learning styles. A person educated in an area having no relationship to his/her learning style may lack confidence and s/he may be less successful; s/he may as a result become frustrated.

Knowledge of learning style also provides information to the student as to why s/he has learnt in a different way than others. It helps to control the process of learning. It is vital because one of the most important signals in learning is to learn to be autonomous, that is, for the individual to take responsibility for his/her own learning. Because of this, s/he should know what learning style is. This has to be part of the learning process to enable the individual to obtain knowledge, which constantly shifts and changes, without any help from others. Briefly, confidence in learning will consistently rise when learners know how to learn. Learning to learn and grasping knowledge in a suitable manner will lessen the need for an overbearing control by teachers. At this point, teachers guide the students. The students take responsibility for their learning, they are at the center of the process and everything 
is under their control. They search answers to the problems and benefit from their unique performances and preferences in their learning styles. Those people will identify their aims, unlike those whose learning style preferences are not identified. They know what they want to learn and "how." This awareness will change their perspectives on learning new things [Fidan, N. (1986).

\section{Conclusions}

The knowledge and understanding of learning styles has become more important as classroom sizes increase and as technological advances continue to mold the types of students entering higher education. While research in this area continues to grow, teachers should make concentrated efforts to teach in a multi-style fashion that both reaches the greatest extent of students in a given class and challenges all students to grow as learners. It is very important to understand and explore each individual's learning style. Analyzing one's own particular learning style can be very helpful and beneficial to the student by aiding them in becoming more focused on an attentive learner, which ultimately will increase educational success. Discovering this learning style will allow the student to determine his or her own personal strengths and weaknesses and learn from them. Teachers can incorporate learning styles into their classroom by identifying the learning styles of each of their students, matching teaching style to learning style for difficult tasks, strengthening weaker learning styles through easier tasks and drill, and teaching students, learning-style selection strategies.

It is important for students to have multiple learning opportunities and "learning style-shift" and teachers should achieve a match between teaching strategies and the students' unique learning styles. Accommodating teaching to learning styles improves students' overall learning results, increases both motivation and efficiency and enables a positive attitude towards the language being learned. The purpose of using learning styles is to find the best ways for both students to learn effectively and teachers to teach efficiently.

\section{Acknowledgments}

Thanks are due to Rector of State University of Padang, Professor Ganefri and The Dean of Economics Faculty, Dr. Idris, M. Si., who have supported the research.

\section{References}

Biggs, J. (2001). Enhancing learning: A matter of style or approach? perspectives on thinking, learning and cognitive styles. R. J. Sternberg, L. F. Zhang (Eds.). Mahwah, Lawrence Erlbaum Associates, N. J. ISBN: 0-8058-3431-1, 276.

Blouin, R. A., Joyner, P. U., \& Pollack, G. M. (2008). Preparing for a renaissance in pharmacy education: The need, opportunity, and capacity for change. Am J Pharm Educ., 72(2), article 42.

Bollinger L. (2003). The need for diversity in higher education. Acad Med, 78, 431-6.

Brown, H. D. (2000). Principles of language teaching and learning. $4^{\text {th }}$ ed. White Plains, NY: Longman.

Celce-Marcia, M. (2001). Teaching English as a second or foreign language. $3^{\text {rd }}$ ed. NY: Dewey Publishing Services: NY.

Coffield, F. (2004). Learning Styles and Pedagogy in Post-16 Learning. A Systematic and Critical Review. London: Learning and Skills Research Centre. ISBN: 18533891889781853389184.

Cook, D. A. (2005). Learning and cognitive styles in web-based learning: Theory, evidence, and application. Acad Med, 80, 266-78.

Cook, D. A. (2005). The research we still are not doing: An agenda for the study of computer-based learning. Acad Med, 80, 541-8.

De Vita. G. D. (2001). Learning styles, culture and inclusive instruction in the multicultural classroom: a business and management perspective. Innovations Educ Teaching Int., 38, 165-74.

DePorter, Bobbi, Mark Reardon, \& Sarah Singer-Nourie. (2014). Quantum Teaching. Bandung: PT Mizan Pustaka.

Dunn, R., \& Dunn, K. (1978). Teaching Students through Their Individual Learning Styles: A Practical Approach. Reston, VA.: Prentice Hall. ISBN: 10: 0879098082, 336. 
Felder, R. M. (1993). Reaching the second tier: learning and teaching styles in college science education. J Coll Sci Teaching, 23, 286-90.

Fidan, N. (1986). Learning and Teaching at School, Concepts, Principles, Methods. Ankara: Publication. ISBN: 975-337-043-1

Garsha A. F. (1990). Using traditional versus naturalistic approaches to assessing learning styles in college teaching. J Excellence Coll Teaching, 1, 23-38.

Jham, B. C., Duraes, G. V., Strassler, H. E., et al. (2008). Joining the podcast revolution. J Dent Educ, 72, $278-81$.

LdPride, N. D. (2009). What are learning styles? Retrieved from http://www.ldpride.net/learningstyles. MI.htm.

Lubawy W. C. (2003). Evaluating teaching using the best practices model. Am J Pharm Educ, 67(3), article 87.

MacKeracher, D. (2004). Making Sense of Adult Learning. $2^{\text {nd }}$ ed. Canada: University of Toronto Press Incorporated

McCarthy, B. (1982). Improving staff development through CBAM and 4MAT. Educ. Leadership, 40, 20-25.

Newble D. I., \& Entwistle N. J. (1986). Learning styles and approaches: Implications from medical education. Med Educ, 20, 162-75.

Qiang Z. (2003). Internationalization of higher education: towards a conceptual framework. Policy Futures Educ, 1, 248-70. 